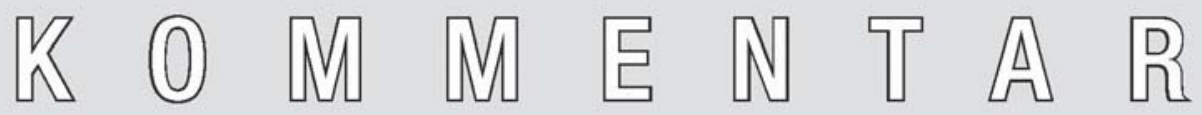

af Rasmus Willig

\title{
Afmontering af kritikken
}

\section{Medarbejderudviklingssamtale}

De fleste skal i dag til en såkaldt medarbejderudviklingssamtale. Bemærk, at der ikke er tale om en arbejdersamtale. Det er ikke længere en arbejder, men en medarbejder der skal til samtale. Den sproglige nuance synes umiddelbart ligegyldig, men der er en forskel. En medarbejder er tydeligvis med. Men med hvad? Medarbejderen er med arbejdet og de andre medarbejdere og med udviklingen. Medarbejderudviklingssamtale. Medarbejderen er med og ikke imod. Medarbejderen er i hvert fald ikke en modarbejder. Der er ikke tale om en klassisk arbejder, der per definition står i et modsætningsforhold til arbejdsgiveren. Medarbejderen er med. Det er en grundpræmis. En præmis, der er givet på forhånd, og som må accepteres af arbejderen.

\section{Sproglige sammentrækninger}

Herbert Marcuse skrev engang meget præcist om sådanne sproglige sammentrækninger:

Virkningen er [...] magisk og hypnotisk, der projiceres billeder, der giver et overvældende indtryk af, at modsætningerne er forenet, $i$ harmoni med hinanden (Marcuse 1969:108).

Hvad mente Marcuse med det? I vores tilfælde betyder det helt konkret, at sammentrækningen af med og arbejder giver et indtryk af, at modsætningerne er forenet. At arbejderen ikke længere er i konflikt med arbejdsgiveren. Er man blevet reduceret til medarbejder, synes den grundlæggende konflikt mellem arbejdsgiver og arbejdstager også at være ophævet. Der er ingen, der giver eller tager - der er kun dem, som er med. Konflikten forbliver en kendsgerning, men den er sprogligt nedtonet.

Denne type sproglig forvandling har en ganske særlig funktion. Som Marcuse så det, skal den foregive, at modsætningerne er forenet, og i et harmonisk forhold findes der ingen kritik. Den, der kritiserer under en enhedstanke, kri- 
tiserer på en destruktiv måde. Der er jo ingen grund til at kritisere, hvis der er enighed. Det er devisen, og den er naturligvis falsk. Modsætningsforhold og kritik ophører ikke, blot fordi sproget skifter form. På et strukturelt niveau er der altid et grundlæggende modsætningsforhold mellem arbejdsgiver og arbejdstager. Arbejdsgiveren udøver sin magt for at få den størst mulige afkast, og den kan han/hun kun sikre ved, at arbejdstagerne tager arbejdet til den lavest mulige løn.

Den opmærksomme læser kan allerede se, at vi har at gøre med flere sproglige sammentrækninger. Arbejdsgiveren giver arbejdet. Nærmest som et offer, en gave eller en håndsrækning. Han foretager en altruistisk handling. Der er tydeligvis ikke tale om en arbejdstvinger, selv om det i visse tilfælde sikkert vil være en mere rammende betegnelse. Der er også en arbejdstager. Arbejdstageren tager arbejdet. Tager imod det. Tager imod gaven. Et vedkommende forhold: Den ene part er den, der giver, den anden part er den, der tager. Den, der tager, kan aldrig være generøs, men kun berige sig eller tage noget. Der er aldrig tale om et gensidigt udvekslingsforhold. Den, der er arbejdstager og tager imod, er logisk nok utaknemlig, hvis vedkommende afstår, er utilfreds eller endog takker nej. Med andre ord: Hvis gaven, den andens offer eller almisse, kritiseres, betragtes det som utilstedeligt og uforskammet. Det er nærmest barnagtigt. Det er som bekendt kun børn, der endnu ikke har lært, at man ikke kritiserer de gaver, man får, eller sætter spørgsmålstegn ved deres værdi. Den, der kritiserer, etablerer derfor også en radikal asymmetri, som tillader en hvilken som helst arbejdsgiver (gave-giver) at tale ned til det umyndige barn.

Teoretisk set kan forholdet vendes om, men i praksis er det nærmest en umulighed: Kun i de tilfælde, hvor efterspørgslen på arbejde er større end udbuddet, kan der være en chance for, at forholdet reelt vendes om, og arbejdstageren kan være mere selektiv og tage de bedste tilbud. I disse få tilfælde byttes de to sproglige betegnelser om, for så bliver det arbejdstageren, der giver arbejde, og arbejdsgiveren, der må tage imod det. Men historisk set er det en sjældenhed.

\section{Kastreret kritik: Modarbejderdiskussionen}

Så langt, så godt. Nu ved vi lidt mere om medarbejderen, men vi mangler samtalen. Medarbejderudviklingssamtalen. Igen er der en sproglig sammentrækning: Det er en medarbejder, der samtaler. Det er ikke en medarbejderdiskussion, og det er bestemt ikke en modarbejderdiskussion. Samtalen signalerer, at der sam-tales, ikke mod-tales. Der er på forhånd etableret en pagt. Eventuelle konflikter er allerede udelukket. Medarbejderudviklingssamtaler er i dag forkortet til MUS-samtaler. Marcuse, som jeg citerede ovenfor, har følgende betragtning om sådanne forkortelser:

Forkortelser betegner udelukkende det, der er institutionaliseret i en sådan grad, at de transcenderede bibetydninger er skåret bort. Betydningen er stivnet, kastreret, forfalsket. Så snart forkortelsen er blevet en del af det officielle ordforråd, ustandseligt gentaget i almindelig sprog- 
brug [...] har den mistet enhver erkendelsesværdi og tjener kun til at betegne en uomtvistelig kendsgerning (Marcuse 1969:109).

Marcuses pointe er, at det er de potentielle kritikker, der er skåret bort. Det er det, han mener, når han refererer til "bibetydninger" - bibetydninger, der ikke passer ind i den herskende betydningskodeks. Bibetydningerne er transcendente, og det transcendente aspekt knytter sig ikke til overskridelse i religiøs, men i verdslig forstand.

Bibetydningerne - det kunne f.eks. være en kritik af arbejdsgiveren - skæres bort. De hører ikke hjemme, eller også kan de slet ikke trænge igennem. En medarbejderudviklingssamtale kan aldrig blive til en modarbejderdiskussion, selv om det ville kunne føre til fremskridt for både arbejdstager og arbejdsgiver. Med den etablerede forkortelse er medarbejdersamtalen stivnet og tjener ifølge Marcuse kun "til at betegne en uomtvistelig kendsgerning", nemlig den præmis, at der fra først til sidst hersker en grundlæggende (her kunne man så tilføje: falsk) konsensus. Kritik er således i bund og grund umulig.

Men hvad samtales der om i medarbejderudviklingssamtalerne? Der tales om det, der skal udvikles, nemlig medarbejderens talenter, færdigheder og evner. Men hvilke talenter, færdigheder og evner? Og hvad er deres konkrete indhold? De specifikke evner, færdigheder og talenter, der skal udvikles, skal ses i forhold til arbejdspladsens overordnede værdier og målsætninger. I andre tilfælde kan det også være i forhold til mere konkrete målsætninger, men de vil i så fald være underlagt de overordnede værdier. Lad os se nærmere på dem.

\section{Samtidens musikalitet}

Endnu en ideologisk illusion har føjet sig til rækken af organisatoriske målsætninger i stil med fleksibilitet, mobilitet og kreativitet, nemlig musikalitet. ${ }^{1}$ Det danske udenrigsministerium har bl.a. indarbejdet "Musikalitet" som en af de værdier, ministeriet værdsætter hos sine medarbejdere. Ingen kan eller vil give en præcis definition af dette begreb. Held og lykke til dem, der skal til medarbejderudviklingssamtale, for hvordan skal vi overhovedet forstå musikalitet som en organisatorisk målsætning?

Måske betyder det, at den medarbejder, der har fornemmelse for, hvornår samtidens toneleje skifter, har en chance for at blive belønnet. Fornemmelser for, hvor resten af orkestret er på vej hen, hvornår det er opportunt at spille solo, duet eller trio. De, der ikke har sans for, hvordan klaveret spiller eller ikke forstår, at takt og tone betyder noget ganske andet end normal høflighed, må affinde sig med deres nye status som tonedøve.

Vor tids udviklingsmålsætninger - fleksibilitet, mobilitet, kreativitet og nu musikalitet - har det tilfælles, at de er uden endemål. Der er ingen klare og entydige kriterier for, hvornår en medarbejder kan siges at være fleksibel, mobil, kreativ eller musikalsk nok. Ganske vist er der i dag delte meninger om, 
hvad der ligger i de forskellige begreber, men der er en tydelig uoverensstemmelse eller diskrepans mellem målsætningerne og virkeligheden: Fleksibilitet er reelt ensbetydende med overarbejde, der ikke kan afspadseres. Mobilitet betyder, at man ufrivilligt må flytte afhængigt af arbejdspladsens nye fysiske rammer. Kreativitet medfører ikke udvidede muligheder for udfoldelse, men derimod et tvingende krav om at levere produktive ideer. Og det nye skud på stammen, musikalitet, betyder ikke, at der er givet plads til æstetisk stimulerende oplevelser, men at medarbejderne skal være omstillingsparate over for organisationens vilkårlige rytmer.

\section{Kognitiv diskrepans}

I lyset af sådanne organisatoriske målsætninger kan ingen medarbejdere vide, hvilke talenter, færdigheder og evner der kan resultere i belønning, anerkendelse eller prestige. Målsætningerne er simpelthen så abstrakte, at de ikke giver mening i det konkrete arbejde. Målsætningernes kvalitative karakter gør, at de er umulige at afslutte, og så længe den slags kvalitative bedømmelseskriterier er gældende, er det heller ikke muligt at puste ud, endsige holde en velfortjent pause, inden partituret igen ændrer karakter. Et rigtigt Sisyfosarbejde.

Et præcist psykologisk begreb til at beskrive denne stressfulde tilstand er kognitiv diskrepans - at der altså ikke er overensstemmelse mellem medarbejdernes forudsætninger og arbejdspladsens målsætninger. Den kognitive diskrepans beskrives ofte som et psykisk chok, hvor de ramte står måbende tilbage. Det er imidlertid ikke de musikalske toner af Mozarts klaverkoncerter, der tryllebinder dem, men derimod nutidens organisation, der dirigeres i et tempo, som ingen kan holde trit med.

\section{Hvad giver anerkendelse?}

Den kognitive dissonans i orkestergraven betyder, at ingen kan høre, hvilke tonearter (præstationer) der giver anerkendelse. Hverken rytme- eller blæsersektionen kan kognitivt vide, hvilke af deres talenter de skal fremhæve, hvilke tillærte evner der skal tages i anvendelse, eller hvilke præstationer dirigenten sætter pris på. Forvirringen er total, ideen om frihed under musikalske organisatoriske målsætninger en illusion. Det kan derfor ikke undre, at stress og udbrændthed er udbredte træk hos dem, der er underlagt disse organisatoriske principper. Ingen ved, hvad der vil ske, og hvilke evner, færdigheder eller talenter der kan give belønning. Der er faktisk ingen, der ved, om deres specifikke tillærte evner stadigvæk vil blive belønnet. Fortidens tillærte kvalifikationer er passé, og potentielle, endnu ikke tillærte kvalifikationer hører fremtiden til, men det skaber en ny uset angst, som den amerikanske sociolog Richard Sennett definerer således:

Angst retter sig mod noget, der måske vil ske, hvorimod frygt retter sig mod noget, der vil ske. Angst opstår inden for dårligt definerede ram- 
mer, frygt derimod når smerten eller ulykken er veldefineret (Sennett 2007:48).

Den nye angst består i rytmesektionens vilkårlige rytmer, hvor takten ikke kan aflæses. Hvis der overhovedet kan fremanalyseres nogen kvaliteter inden for disse rammer, er det for det første, at den moderne medarbejder skal improvisere sin livsfortælling eller ligefrem klare sig uden nogen langtidsholdbare forestillinger om sin personlighed. For det andet skal medarbejderen fremhæve potentielle evner frem for allerede frembragte resultater og færdigheder, og for det tredje skal han eller hun være i stand til - helt kynisk - at give slip på sin fortid, eftersom der ikke længere er nogen garantier for, at man kan blive på sin nuværende arbejdsplads. Det gælder om at dæmpe den emotionelle tilknytning (Sennett 2007:11). Når man giver slip på sin fortid og dæmper den emotionelle tilknytning, svækkes muligheden for kritik også. Marcuse udtrykker det præcist således:

Erindring om fortiden kunne skabe en farlig indsigt, og det bestående samfund er tilsyneladende ængstelig for erindringernes undergravende indhold. Erindringerne er en måde, hvorpå man kan afskære sig fra de givne kendsgerninger, en form for "formidling", der for korte perioder bryder de givne kendsgerningers allestedsnærværende magt (Marcuse 1969:113).

Hvad Marcuse hentyder til, er, at "erindringen" kan stå i et modsætningsforhold til "situationen". "Det tidligere" udgør noget, der er forskelligt fra "det eksisterende", og denne forskel udgør et kritisk spændingsforhold. Tænk blot på den medarbejder, der udbryder: "Sidste gang vi lavede den manøvre, gik det helt galt!"

Det handler med andre ord om at udvikle en mental grundholdning, der indebærer viljen til konstant at være omstillingsparat. Men omstillingsparathed kan ikke anerkendes som en værdi i sig selv. Hvad er det, der omstilles til? Det, der stilles om til, fungerer som baggrundsværdien for, om det kan blive et objekt for anerkendelse. Udsagnet: "Nu er jeg omstillet" har ingen mening, hvis vi ikke ved, hvad der er blevet omstillet til hvad. Bevægelsen og om den er foretaget for hurtigt - om medarbejderne altså er parat - er ikke belønningsværdig i sig selv. Det er stadigvæk opgavernes og projekternes karakter, der bestemmer graden af belønning.

Men der er et andet træk ved omstillingsparathed, som er værd at fremhæve. Det er, polemisk udtrykt, et prostitueret begreb. Det er parat til hvad som helst når som helst, og der er ingen grænser for, hvilken stilling det vil indtage. Det stiller om på sengelinnedet efter ordre. I denne betydning er det også ligegyldigt, hvad der stilles om fra og til. Den ene stilling er lige så god som den anden, når blot den altid kan overskrides (med en ny og mere pervers). Den 
omstillingsparate medarbejder er en umyndiggjort person. Myndige personer kan nemlig sige fra og selv vælge. Det kan omstillingsparate individer ikke. Medarbejderen kan meget vel være parat, men denne parathed indebærer noget helt andet - for den foregår på egne præmisser. Den, der ligger under for kravet om altid at være parat til omstilling, er per definition kritikløs. Kritik er ikke omstilling, men i højere grad stillingtagen, og den, der tager stilling, kan ikke altid være parat til hvad som helst. "Sådan vil jeg ikke tages."

\section{Kritikken er uden objekt: Skydeskiven rykkes}

Når medarbejdere ikke kan erkende, hvad der kan give anerkendelse, mister de ikke kun fornemmelsen af, hvad der er gode og dårlige præstationer, men også af, hvad der er rimelige og urimelige arbejdsbetingelser. De kan ikke fastholde fornemmelsen af kritisable forhold, eftersom disse forhold hele tiden ændrer sig. Kritikken bliver lige så ukonkret som de tomme, kvalitative målsætninger, og den forsvinder. Den kritiske stilhed skyldes altså, at ingen kan sætte grænserne for eller definere, hvad der er fleksibelt, kreativt eller musikalsk, og det betyder, at objektet for kritik ikke kan fastholdes. Skydeskiven rykkes hele tiden, intet kritisk våben kan ramme plet mere end en enkelt tilfældig gang, og herved bliver det umuligt at samles og gøre fælles modstand. Skulle det lykkes at dele de fælles erfaringer, er der ingen fare for, at kritikken får fat: Der hersker ikke blot en udpræget ekstern, men også en intern konkurrence mellem medarbejderne, og den forøger i sig selv angsten, fordi grænsen mellem konkurrent og kollega er blevet uklar. Angsten har den konsekvens, at ingen bekender kulør. At kritisere er således ensbetydende med at vise, at man ikke kan leve op til arbejdspladsens målsætninger; at kritisere åbenlyst er at udstille sig selv som en fiasko.

\section{Filosofisk og sociologisk musik}

Med filosoffen Hannah Arendts ord bliver det under sådanne betingelser umuligt "to act in concert". Betydningen af hendes "musikalske" metafor er imidlertid fjernt fra nutidens idé om musikalitet, for den handler om muligheden for en endnu ikke opdaget humanistisk toneart. Det samme gør sig gældende for den føromtalte sociolog Richard Sennett, når han anvender sine egne erfaringer fra cellospillet til at angribe forholdet mellem det musikalske talent og lighedsidealet. En anden sociolog, Howard S. Becker, der selv er en fremragende jazzmusiker, anvendte i sit mest berømte studie musikere som undersøgelsesmateriale, eftersom de blev kategoriseret som afvigere på grund af deres hashforbrug.

Disse metaforer tjente og tjener et oplysningsideal, mens samtidens skud på det organisatoriske stamtræ tjener den kritiske stilhed. Det spørgsmål, der står tilbage for såvel musikere som publikum, er, hvem der inkasserer den kritiske stilheds merværdi. 


\section{Tilbage til medarbejdersamtalen}

Det er ikke svært at sætte sig i ind i medarbejderudviklingssamtalens sammensatte og vanskelige forløb med sådanne organisatoriske målsætninger. Der spørges - systematisk efter dertil indrettede skemaer - ind til, hvordan den pågældende medarbejder kan leve op til og udvikle sig i forhold til idealer om at være mobil, fleksibel og musikalsk. Der er ofte forskellige trin i udviklingssamtalen, og efter et afsluttet samtalepunkt placerer medarbejder og arbejdsgiver derfor i fællesskab medarbejderen på en skala fra 1 til 10, f.eks. 7 i musikalitet. Det er en umulig øvelse, eftersom et kvalitativt forhold som musikalitet ikke kan kvantificeres. Men man gør alligevel det ikke-målelige måleligt. Det tjener muligheden for at sammenligne udviklingen, sammenligne medarbejderne og vurdere den pågældende medarbejder over tid. Fra år til år. Er der sket en udvikling? Er medarbejderen blevet bedre eller dårligere? Det foregøgler grundighed. Vi tager os tid. Sammen. Samtale med medarbejderne. Medarbejderudviklingssamtale. Men den grundige samtale er i princippet en effektiv disciplineringssamtale. Et stykke professionel dressur. Jo flere omgange i manegen, desto bedre trit. Men det er ikke en grundighed, som man kunne ønske sig: En modarbejderdiskussion, hvor alle kritikker kommer frem og bliver behandlet.

Der er mange punkter ved en medarbejdersamtale, ikke kun fordi det foregøgler grundighed, men også fordi muligheden for effektivisering øges i takt med punkternes antal. Jo større differentiering, desto flere muligheder for finjustering. Det er umuligt at nå en topscore på $100 \%$. Der er altid plads til forbedringer. Et mærkværdigt system, hvis endemål er perfektion, men som ikke har nogen målstreg. Det er der en årsag til. Uden endemål - intet objekt for reel kritik af organisations målsætninger.

\section{Kritikken forsvinder med detaljen}

Finjusteringen af medarbejderes evner og præstationer kan være meget godt, men forestil dig, at der bliver fremsat kritik i løbet af samtalen. Det uønskede sker. Der er en medarbejder, der for en kort stund er blevet en modstandsarbejder. Nu tjener de mange udviklingsmål noget helt andet, nemlig det forsvarsskjold, som avancerede krigsherrer benytter sig af, når de er trængt. De skyder med spredehagl for at forvirre fjenden (modarbejderen). Nu virker metaforen måske ikke, fordi vi forbinder noget andet med den, nemlig at der søges skudt i alle retninger. Det bliver der i og for sig også, men der er snarere tale om en undvigelsesmanøvre end om et angreb: Spredningen af spørgsmål, der udspringer af de fastsatte udviklingsmål. Der er så mange spørgsmål, at modarbejderen hurtigt dukker sig og går i dækning, og i det øjeblik er vedkommende igen blevet en medarbejder. Det er en velkendt undvigelsesmanøvre. Der sættes flere skibe i søen, og imens kan landgangen foregå ubemærket et andet sted. Dette modtræk anvendes gerne under voldsomme kritikker, der rammer hårdt. Igen er det sådan, at jo flere spørgsmål og argumenter der fremføres, jo bedre mu- 
ligheder har man for at hæfte sig ved ubetydelige detaljer. Det flytter fokus væk fra de hårdt ramte områder. Tiden går med detaljer - og kritikken dør hen.

\section{Individualiseret ansvar}

Alle medarbejderudviklingssamtaler indebærer også muligheden for kritiske spørgsmål og afvejning, dvs. medarbejderen kan få lov at være en konstruktiv medarbejder. Det er vigtigt, at det er konstruktivt. "Konstruktivt" betyder i denne sammenhæng, at det ikke strider imod de grundlæggende vedtagelser, men kan hjælpe til en større effektivisering af de tiltag, der allerede er under implementering. Kritikker, der rækker ud over, overskrider, transcenderer, er ikke konstruktive og derfor ligegyldige. Der er mange tilfælde, hvor en medarbejder påpeger noget strukturelt forkert. Det kan f.eks. meget vel være, at medarbejderen påpeger en generel dårlig trivsel på arbejdspladsen, et problemområde, som arbejdsgiveren har ansvaret for. Det er efterhånden mere reglen end undtagelsen, at ledelsen svarer: "Hvad kan du bidrage med, for at vi kan få en bedre trivsel?" Bemærk det lille "du", der skal præstere for det store "vi". Et strukturelt forhold kritiseres, nemlig en generel dårlig trivsel, og kritikken returneres til medarbejderen på et individuelt niveau. Det ledelsesmæssige ansvar er pludselig blevet et individuelt ansvar. Det er medarbejderen, der skal tage et medansvar.

\section{Objektive fakta, subjektive meninger}

Under en medarbejdersamtale kan talen falde på faktuelle misforhold på arbejdspladsen. Den sidste trivselsundersøgelse kan f.eks. være et varmt emne. Medarbejderen henviser måske direkte til undersøgelsen og slår måske oven i købet op på den pågældende side og siger insisterende, "at der bør gøres noget, når over 80 \% af medarbejderne mener, at de er for stressede“. I sådanne tilfælde er det ikke usædvanligt, at arbejdsgiveren siger noget i retning af: "jeg læser det anderledes" eller "sådan forstår jeg det nu ikke".

Situationen fremkalder spørgsmålet om, hvem der har fortolkningsretten. Hvem befinder sig i en position, der gør det muligt for vedkommende at tolke tallene rigtigt? Arbejdsgiveren må også gøre indrømmelser. Hvis alt kategorisk afvises, kan det føre til en voldsom kritik, og det har arbejdsgiveren ingen interesse i. Derfor skal der gøres indrømmelser. De må bare aldrig være så omfattende, at de reelt ændrer de grundlæggende strukturelle forhold. Det gælder om at kunne give efter - uden at det sætter sig spor.

Når der kommer objektive data på bordet, er det ligegyldigt hvem der har taget initiativet til f.eks. en trivselsundersøgelse, hvis data afslører kritiske forhold. Hvis det er tilfældet, omdefineres kampen blot til at være et spørgsmål om, hvad der er den rigtige fortolkning af data, og hermed bliver det, der var objektivt, lige pludselig et spørgsmål om subjektive meninger. Og når de objektive data er blevet til subjektive meninger, er det den eller de, der har den 
største pondus, magt eller højeste placering i hierarkiet, som sidder inde med fortolkningsretten og dermed kan bestemme, hvad der er rigtigt.

\section{Kritikken afmonteres}

Er der et sporbart mønster i denne polemiske diagnose? Ja, kritikken afmonteres trin for trin. Det skal siges, at den proces, der her er karakteriseret som en afmontering af kritikken, ofte er langt mere kompliceret og indviklet, end jeg har antydet. Mit håb er kun ad negativ vej at fremhæve vor fornemste erkendelsesmiddel, der i øjeblikket er ude af moralsk drift. Kritik leder til moralske og sociale fremskridt. En afmontering tjener ingen.

Lad mig opsummere: For det første afmonteres kritikken i og med, at sproget formgives efter en enhedstanke (der kan også være flere enhedstanker, der konkurrerer om en hegemonisk position, og fælles for dem er, at de er mere ekskluderende end inkluderende), der stigmatiserer andre betydninger. "De andre betydninger" er at betragte som potentielle kritikker, der virker generende eller ubehagelige. For det andet indsættes der værdier, som er uden endemål, således at objektet for kritik aldrig kan fastlåses og dermed skydes i sænk. Skydeskiven flytter sig hele tiden, og det er umuligt at indkredse konkrete pejlemærker for, hvordan de kritisable forhold kan laves om. For det tredje er disse værdier karakteriseret ved en bestemt form for etisk barbari, hvor etiske fordringer tilslører de bagvedliggende instrumentelle intentioner. For det fjerde afmonteres kritikken ved, at der indsættes en niveauforskydning, som flytter ansvaret fra arbejdsgiveren til medarbejderen. De kritikker, der er strukturelt rettet, vender tilbage på et individuelt niveau. Det decentrerer kritikken og flytter ansvaret til medarbejderen, der ikke har de fornødne ressourcer til at løfte opgaven, og derved dør kritikken hen.

Rasmus Willig

E-mail: willig@ruc.dk

\section{Noter}

Jeg trækker her på et bachelorprojekt, som undersøgte udenrigsministeriets værdier. Gruppens arbejde har været til stor inspiration for hele essayet. De skal derfor have en særlig tak.

\section{Litteratur}

Marcuse, Herbert [1964] 1969: Det endimensionale menneske. København: Gyldendal.

Sennett, Richard [2005] 2007: Den ny Kapitalismens kultur. Højbjerg: Forlaget Hovedland. 